\title{
FACTORS AFFECTING A MECHANICAL COATING OF SESAME SEEDS
}

\author{
Alaa H. A. Mohamed ${ }^{(1)}$
}

\section{ABSTRACT}

The aim of this research is to study the factors affecting a mechanical coating of sesame seeds. These factors are coating speed, temperature and time, and seed batch. The main results in this study can be summarized in the following points:

* The maximum sesame-seed germinations of 55.1, 65.3 and $55.8 \%$ by using coating-unit speed of $28 \mathrm{rpm}$, coating time of 15 minute, coating temperature of $30 \mathrm{C}^{o}$ and coating with " $\mathrm{Fe}+\mathrm{Zn}$ ", "Fe $+\mathrm{Zn}+$ Cersan" and clay respectively. Meanwhile, the minimum sesame-seed germinations of 2.1, 6.3 and $4.4 \%$ by using coating-unit speed of 36 rpm, coating time of 65 minute, coating temperature of $70 \mathrm{C}^{\circ}$ and coating with the same constitutions respectively. The germination of sesame-seeds without coating was $50.1 \%$.

* The maximum machine capacity of coated sesame-seeds of $4.2 \mathrm{~kg} / \mathrm{h}$ was obtained using seeds-batch mass of $2.5 \mathrm{~kg}$ and coating-unit speed of 36 rpm. Meanwhile, the minimum machine capacity of coated sesameseeds of $0.85 \mathrm{~kg} / \mathrm{h}$ was obtained using seeds-batch mass of $0.5 \mathrm{~kg}$ and coating-unit speed of $20 \mathrm{rpm}$.

* The operation and production costs at optimum parameters (batch mass of $2.5 \mathrm{~kg}$, coating-unit speed of $28 \mathrm{rpm}$, coating temperature of $30{ }^{\circ} \mathrm{C}$, coating time of 15 minutes and coating with " $\mathrm{Fe}+\mathrm{Zn}+$ Cersan") were 10.63 L. E./h and 3037 L.E./ton.

\section{INTRODUCTION}

eeds vary greatly in size, shape and color. In many cases, seed size is small or irregular, making singularization and precision placement difficult. In addition, seeds should be protected from a range of pests that attack germination seeds or seedlings. Seed-coating technologies can be employed for two purposes:

(1) Researcher. Ag. Eng., Res. Inst. 
They can facilitate mechanical sowing to achieve uniformity of plant spacing, and can act as a carrier for plant protectants. So materials can be applied in the target zone with minimal disruption to the soil ecology and environment (Taylor et al., 1998).

Film coating is a method adapted from the pharmaceutical and confectionery industries for uniform application of materials to seeds. The film forming formulation consists of a mixture of polymer, plasticizer and colorants (Halamer, 1998 and Robani, 1994), and formulations are commercially available that are ready-to-use liquids or prepared as dry powders (Ni, 1997). Application of the film-forming mixture results in uniform deposition of material on each seed with little variation among seeds (Halmer, 1998). The formed film may act as a physical barrier, which has been reported to reduce leaching of inhibitors from seed coverings and may restrict oxygen diffusion to the embryo (Duan and Burris, 1997).

A standard pelleting pan has been adapted for application of film-coating polymers, and drying is achieved by applying forced warm air into the coating pan (Taylor and Eckenrode,1993). A small-scale. fluidized bed seed-coating apparatus has been described with controlled air velocity and temperature (Burris et al., 1994). Film coating is routinely performed in vented or perforated pans on a large-scale basis either on a batch or continuos system (Halmer, 1998 and Robani, 1994).

Film coating is versatile as a coating system or a component of a coating system. Colorants as aesthetic appeal to seeds, serve to color-code different verities and increase the visibility of seeds after sowing. Filmcoated seeds have better flow characteristics in the planter (Hill, 1997) due to reduced friction between seeds. Film coating provides an ideal method for the application of chemical and / or biological seed treatments (Taylor et al., 1994 and McGee, 1995). Relatively high loading rates of plant protectants can be applied with film coating. However a spatial separation between the plant protectants and seed surface is not obtained as described for pellet loading. A major impetus for using film coating is to reduce exposure of workers to chemicals from treated seeds. 
The cultivated area of sesame reached about 65 thousand feddan in 2005 that produces about 388 thousand ton per year (Agricultural Statistics Economic Affair Sector, 2006).

El-Habbal et al. (1995) proved that coating sesame seeds with fertilizer containing $\mathrm{Fe}, \mathrm{Mn}$ and $\mathrm{Zn}(2: 1: 2$ by weight) at the rate of $6.5 \mathrm{~g} / \mathrm{kg}$ seeds gave significant increments in number of spikes/plant, grain mass/plant and both grain and straw yields/fed. Rehm (2003) found that coating the soybean seeds with iron increased the yield from 2.1 to $11.7 \mathrm{bu} / \mathrm{acre}$ compared with the seeds without iron applied. Yehia (2008) concluded that the optimum conditions of coating machine were: coating-unit speed of $28 \mathrm{rpm}$, coating temperature of $40 \mathrm{C}^{\mathrm{o}}$, heat exposure time $30 \mathrm{~min}$, Arabic-gum temperature and concentration $50-110 \mathrm{C}^{0}$ and $25-75 \%$, and grain-batch mass $1-4 \mathrm{~kg}$. The results obtained at optimum conditions were: germination of coated wheat-grain $=98.1 \%$, coatingmachine performance $=3-12 \mathrm{~kg} / \mathrm{h}$, mass of 1000 coated-grain $=95.7-$ $98 \mathrm{~g}$, external and internal friction-angles $=18-20.5$ and $21-23.5$ degree, by using fe $+\mathrm{Zn}$ coated wheat-seeds: grain emergence $=94.2 \%$, grain yield $=2186 \mathrm{~kg} / \mathrm{fed}$ and net profit $=1195$ L.E./fed (531 L.E./ton). Yehia et al. (2010) found that the maximum fennel, caraway, coriander, nigella and guar seeds germination of 98.1, 96, 98, 100 and $100 \%$ were obtained with coating temperature of $40 \mathrm{C}^{\mathrm{o}}$ and coating time of $30 \mathrm{~min}$. Meanwhile, the minimum fennel, caraway, coriander, nigella and guar seeds germination of $63.38,61.43,66.3,67.76$ and $70.2 \%$ were obtained with coating temperature of $70 \mathrm{C}^{\mathrm{O}}$ and coating time of $70 \mathrm{~min}$. Abd-Al Fattah (2016) found that the highest germination percentages of $100,98.5,97.5$ and $99.5 \%$ were obtained at $28 \mathrm{rpm}$ coating speed, $30^{\circ} \mathrm{C}$ coating temperature and $15 \mathrm{~min}$ coating time for onion, pepper, tomato and cotton seeds respectively.

The objective of this paper is to study the factors affecting a mechanical coating of sesame seeds such as coating temperature and duration, coating unit speed, concentrate and seed quantity inside coating unit on seed germination and machine productivity. In addition, study includes the effect of sesame-seeds coating with some trace elements of " $\mathrm{Fe}+\mathrm{Zn}$ ), fungicide of "Cersan $2 \%$ " and clay on germination percent and crop productivity. 


\section{MATERIALS AND METHODS}

\section{The designed coating machine:}

The coating machine used in this study was designed by Abd-Al Fattah et al. (2015) and Abd-Al Fattah (2016). Views and photograph of the coating machine are shown in figs. 1 and 2. The main specifications of this machine are: total height $60 \mathrm{~cm}$, width $50 \mathrm{~cm}$, depth $40 \mathrm{~cm}$, and total mass $18 \mathrm{~kg}$. The main coating machine parts are as follows:

(1) Frame: made of steel sheet with thickness of $2 \mathrm{~mm}$, height of $50 \mathrm{~cm}$, width of $40 \mathrm{~cm}$ and depth of $50 \mathrm{~cm}$.

(2) Coating pan or unit: made of copper sheet with thickness of $3 \mathrm{~mm}$. The coating pan has an elliptical shape with diameter of $35 \mathrm{~cm}$, depth of $35 \mathrm{~cm}$ and with feeding opening of $22 \mathrm{~cm}$ diameter.

(3) Coating-unit shaft: The coating-unit shaft is made of steel with diameter of $20 \mathrm{~mm}$ and length of $100 \mathrm{~mm}$. The first edge of coatingunit shaft welded with a flange. The flange of $100 \mathrm{~mm}$ diameter is connected with the coating unit by 4 bolts of $10 \mathrm{~mm}$ diameter. The second edge of coating-unit shaft has a cut with $30 \mathrm{~mm}$ length. The cut-shaft part was interfered with the same slot in a ring welded inside the flange of the coating pan. The ring height is $30 \mathrm{~mm}$.

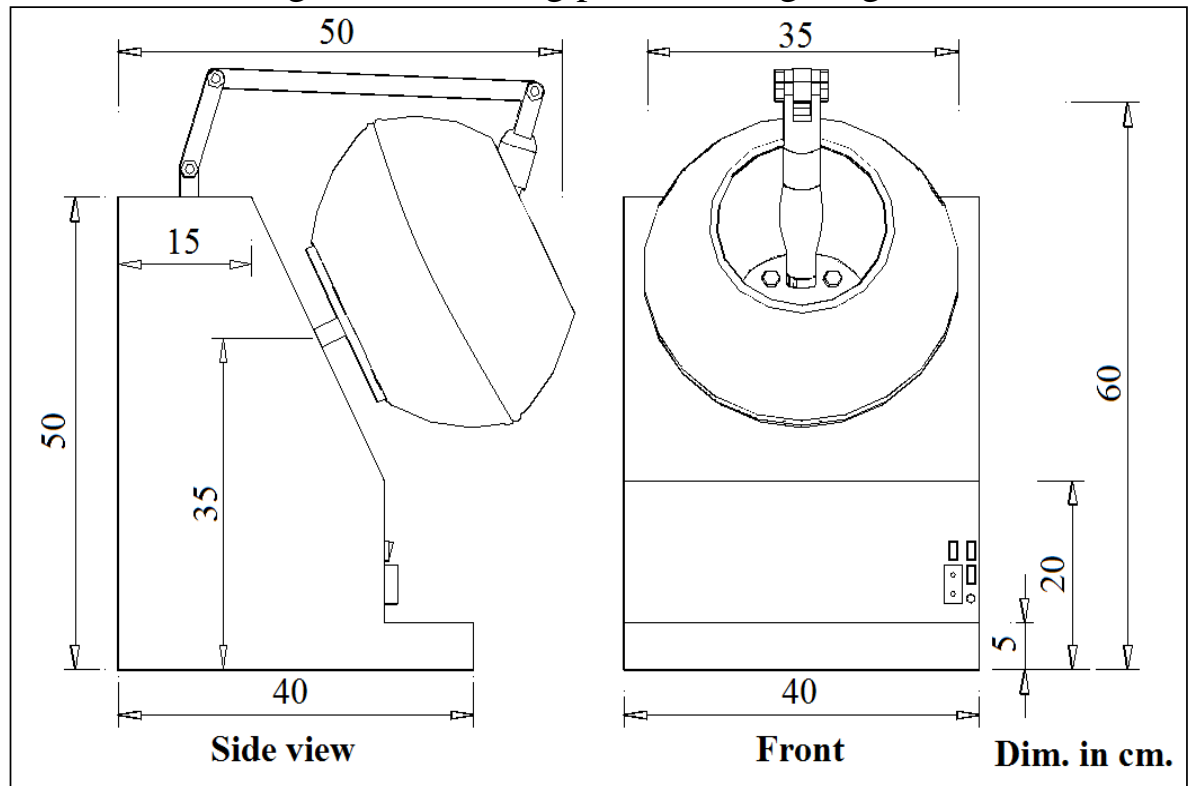

Fig. 1: Views of a seed-coating machine Abd-Al Fattah et al. (2015) and Abd-Al Fattah (2016). 


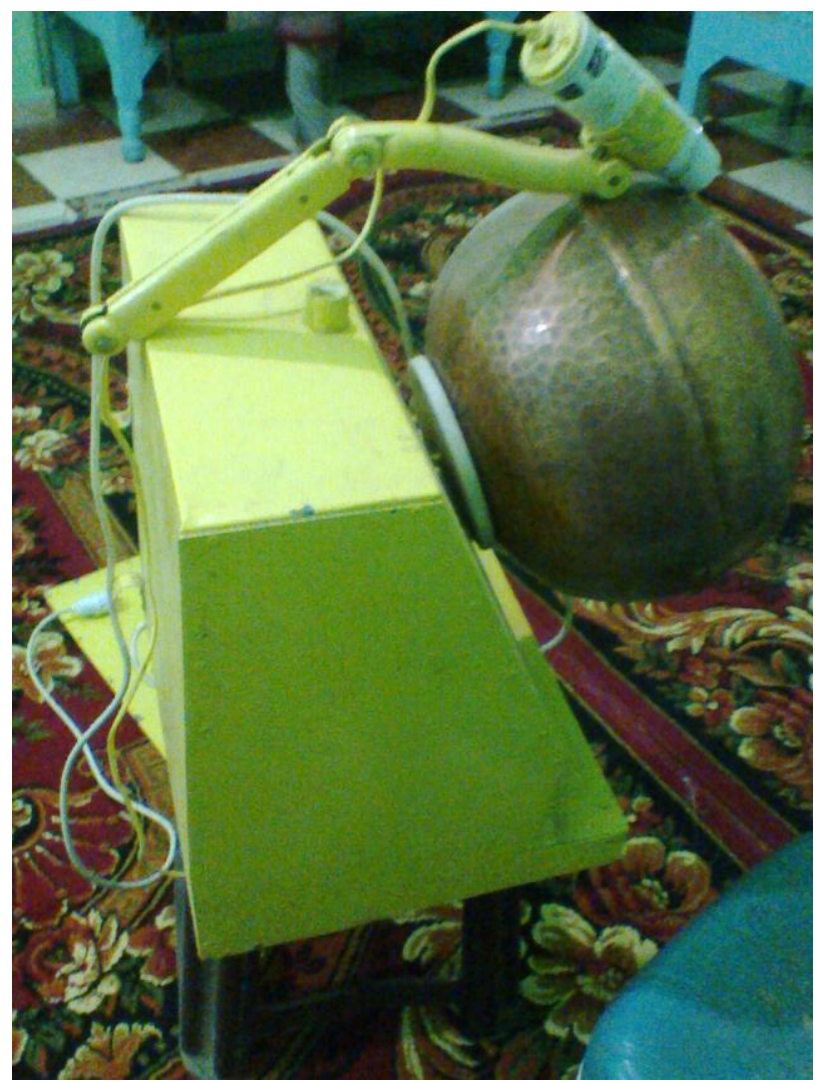

Fig. 2: Photograph of the seed-coating machine Abd-Al Fattah et al. (2015) and Abd-Al Fattah (2016). .

(4) Hot-air dryer: The hot-air dryer consists of case, electric motor, fan, and heater. The hot-air dryer is attached with coating-machine frame by two hinged links to enter and exit it inside or outside the coating pan. The main dimensions of the hot-air dryer are: diameter of 35 $\mathrm{mm}$ and length of $180 \mathrm{~mm}$. Section of hot air-dryer is shown in fig. 3 . The specifications of hot-air dryer are:

Type: hair dryer.

Made in: China.

Power: 500 Watt.

Power source: alternating current.

Thermal fuse: Threaded heat-wire.

Air speed: more than $0.5 \mathrm{~m} / \mathrm{s}$. 
Temperature: $40-45{ }^{\circ} \mathrm{C}$.

Mass: $390 \mathrm{~g}$.

The dryer-motor specifications are:

Model number: TRS-385SP.

Size: 22.7 x $37.8 \mathrm{~mm}$

Voltage range: $3.6-30 \mathrm{~V}$. Voltages are varied by rjoostat.

Speed: $1500-2000 \mathrm{rpm}$. Speeds are varied by voltages variation.

Torque: 90 - 1000 N.cm.

(5) Two hinged-links: Two hinged links connect the hot-air dryer with coating-machine frame. The two hinged links are used to enter and exit the air dryer inside or outside the coating pan and adjust the distance between seeds and hot-air dryer head. The two hinged-links are made of plastic tube with diameter of $40 \mathrm{~mm}$ and thickness of 3 $\mathrm{mm}$. The first link which connects with the air dryer has $200 \mathrm{~mm}$ length. The second link which connects with seed-coating frame with $200 \mathrm{~mm}$ length.

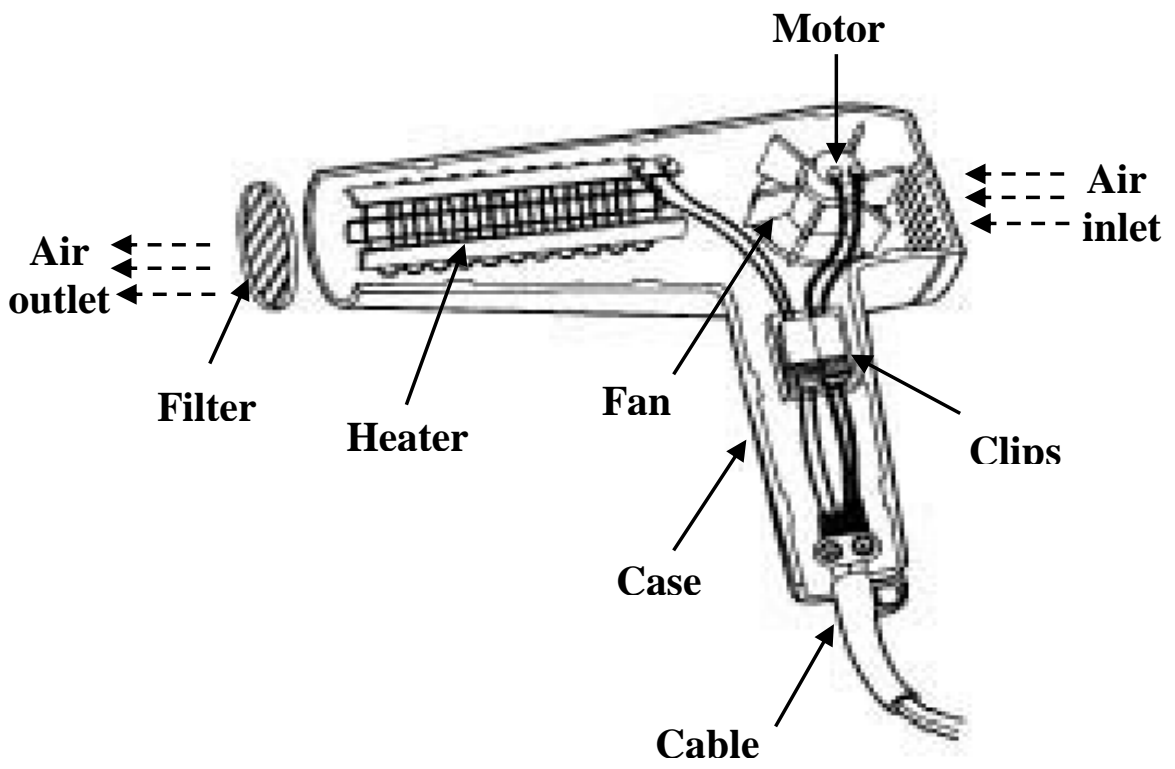

Fig. 3: A section sketch of hot air-dryer.

(6) Power unit: Power unit consists of DC-motor, transformers, bridge, switches and electric cables. Power circuit is shown in fig. 4.

- DC-motor: DC motor specifications are shown in table 1. 
- Transformer: Two transformers were used to obtain the voltages which gave the tested coating speeds. The first transformer gives 6 and 12 volts. The two negative and positive edges of 6 volts are connected with a switch which gives a coating-unit speed of $20 \mathrm{rpm}$. Also, the two negative and positive edges of 12 volts are connected with a switch which gives a coating-unit speed of $36 \mathrm{rpm}$. Meanwhile, the second transformer gives 18 volts. The two negative and positive edges of 9 volts are connected with a switch which gives a coating-unit speed of 28 rpm. Transformer specifications were shown in table 2.

- Bridges: changes alternating to direct current.

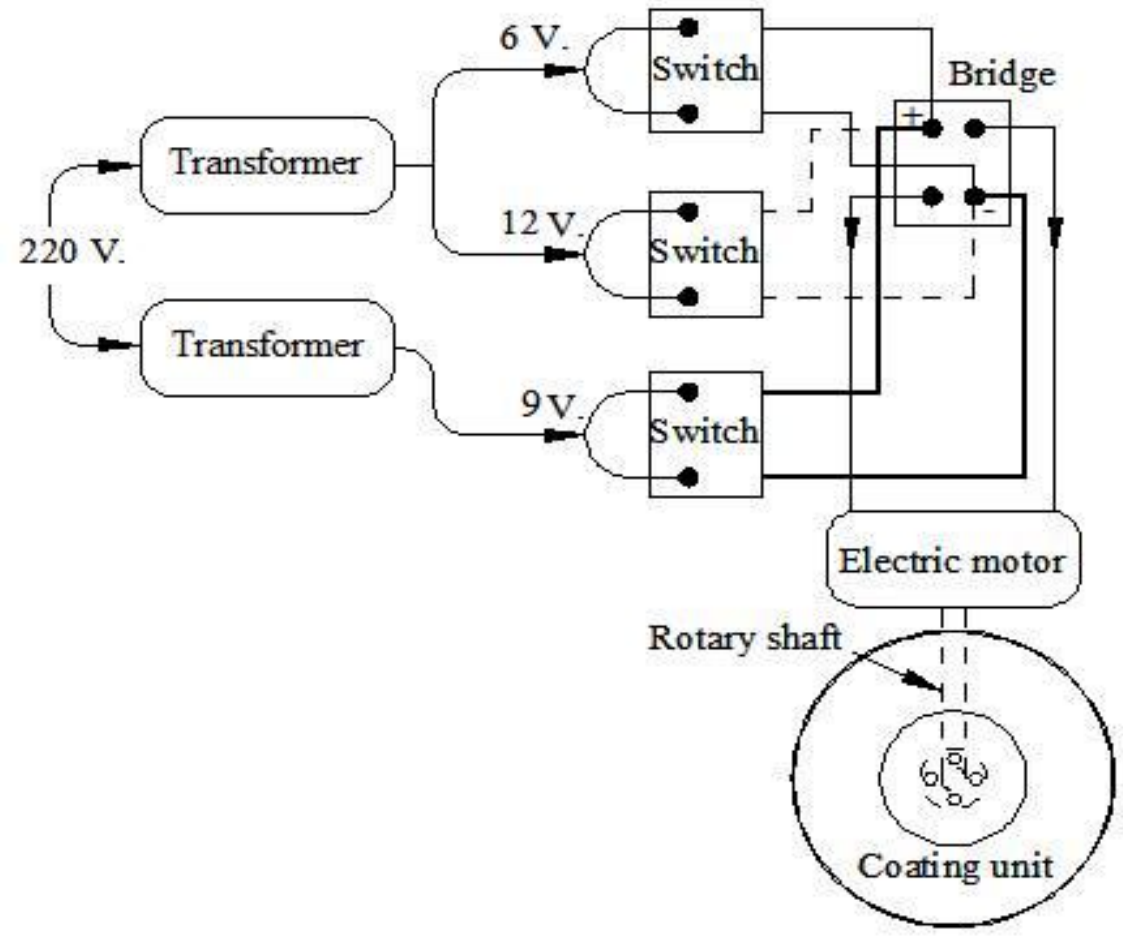

Fig. 4: Electrical circuit of seed-coating machine.

Table 1: Specifications of the DC motor with gear box of $25: 1$ speed ratio.

\begin{tabular}{|l|c|c|c|}
\hline Model: & \multicolumn{3}{|l|}{ GMX -8 PVO 248 . } \\
\hline Made in: & Japan. & 9 & 12 \\
\hline Voltage: & 6 & 28 & 36 \\
\hline Speed, rpm. & 20 & \\
\hline
\end{tabular}


Table 2: Specifications of used transformers.

\begin{tabular}{|l|l|l|l|}
\hline $\begin{array}{l}\text { First } \\
\text { Transformer }\end{array}$ & Type & $\begin{array}{l}\text { PF 4025 } \\
\text { K.002 }\end{array}$ & $\begin{array}{l}\text { Made in } \\
\text { Germany }\end{array}$ \\
\hline \multirow{3}{*}{ First } & Input & $220-240 \mathrm{v}$ & \\
\cline { 2 - 4 } & Out put & $6 \mathrm{~V}-2.6 \mathrm{~A}$ \\
\cline { 2 - 4 } & & $12 \mathrm{~V}-1.6 \mathrm{~A}$ \\
\cline { 2 - 4 } & TF & $130{ }^{\circ} \mathrm{C}$ & \\
\hline \multirow{2}{*}{$\begin{array}{l}\text { Second } \\
\text { Transformer }\end{array}$} & Type & $\begin{array}{l}\text { PF } 4025 \\
\text { K.002 }\end{array}$ & $\begin{array}{l}\text { Made in } \\
\text { Germany }\end{array}$ \\
\hline \multirow{3}{*}{} & Input & $220-240 \mathrm{v}$ \\
\cline { 2 - 4 } & Out put & $9 \mathrm{~V}-2.6 \mathrm{~A}$ \\
\cline { 2 - 4 } & TF & $130{ }^{\circ} \mathrm{C}$ \\
\hline
\end{tabular}

Seed variety: "Giza 138" was used in the experimental tests.

\section{Coating materials:}

- Chemicals: The tested chemicals were: Fe, Zn elements and "Cersan.2 $\%$ " fungicide. Chemicals sesame-seeds ratio of $5 \mathrm{~g} / \mathrm{kg}$ was used.

- Clay: 0.5 liter water was mixed with $1 \mathrm{~kg}$ clay to compose the mud for coating. Mass of $300 \mathrm{~g}$ mud was used to coat $1 \mathrm{~kg}$ sesame seeds for each layer. After coating by first layer, the seeds were cooled in the open air. Then, the second and third coating layers were done by the same procedure.

- Arabic gum solution: $75 \%$ concentration was used (according to Yehia, 2008).

Grain batches: $0.5,1,1.5,2$ and $2.5 \mathrm{~kg}$ were used.

Coating times: $15,25,35,45,55$ and 65 minutes were used.

Coating-unit speeds: 20,28 and 36 rpm were used.

\section{Coating steps:}

(1) Each chemical powder: fertilizer "Fe and $\mathrm{Zn}$ " and fungicide "Cersan $2 \%$ " were mixed with wheat flour powder in the ratio of $5 \mathrm{~g} / \mathrm{kg}$

(2) The wheat flour powder of $0.5 \mathrm{~kg}$ was spread inside the rotated coating pan (unit) which was heated by hot-air dryer. The 
temperature of coating pan and seeds was controlled by heat-control button and the distance between seeds and dryer head.

(3) The sesame seeds batch was spread inside the rotating coating pan.

(4) Arabic-gum solution with $75 \mathrm{~cm}^{3}$ volume was spread on the seeds inside coating pan.

(5) The seeds were agitated by hand to distribute the Arabic gum.

(6) The mixture of chemicals and wheat flour powder of about $70 \mathrm{~g}$ was spread directly after then.

(7) The seeds were agitated by hand to distribute the mixture powder to add it as a layer around the seeds.

(8) The steps from 4 to 7 were repeated until finishing the entourage (first) layer. The entourage layer needs $1: 2$ mixture powder grain ratio.

(9) The seeds exit from coating pan and were spread in the air to dry.

(10) The dried coated-seeds were put inside coating pan.

(11) The steps from 4 to 7 were repeated until finishing the jacket layer. The jacket layer needs $0.3: 1$ wheat-flour powder seed ratio.

(12) The seeds exit from coating pan and were spread in the air to dry.

Germination test: Germination test was conducted by using 100 seeds which was planted in foam bins with 100 eyes, temperature range from 37.9 to $40{ }^{\circ} \mathrm{C}$, light intensity 210 (fot-candle) and Relative humidity "RH"

$85 \%$. The seed germinations were measured after $7-10$ days at different tested parameters.

Estimating the machine capacity: Seed-coating machine capacity calculated by using the following equation:

$$
P_{m}=\mathrm{W} / \mathrm{T}
$$

Where

$\mathrm{P}_{\mathrm{m}}=$ Machine capacity, $\mathrm{kg} / \mathrm{h}, \mathrm{W}=$ Mass of coated seeds, $\mathrm{kg}$ and $\mathrm{T}=$ Coating time, $\mathrm{h}$. 
Solubility in soil: For this study, solubility in soil was determined as the weight of the film that is dissolved after incorporating coated-seeds in soil. A circular film sample was cut from each film, dried at $100 \pm 2^{\circ} \mathrm{C}$ for $24 \mathrm{~h}$ in a laboratory oven, and weighed to determine the initial dry weight. The solubility in soil of the different composite films was measured by incorporating coated-seeds in soils with moister contents of 10, 20, 40, 60,80 and $100 \%$ and incorporated times of 6, 12, 18, 24 and $30 \mathrm{~h}$. After that period, the remaining pieces of film were taken out and dried at $100 \pm 2^{\circ} \mathrm{C}$ until constant weight (final dry weight). The percentage of the total soluble matter "TSM" of the films was calculated using the following equation: This test for each type of film are carried out in three replicates and average reported (Gontard et al., 1994).

$$
\mathrm{TSM}, \%=\frac{\text { Initial dry weight }- \text { Final dry weight }}{\text { Initial dry weight }} \times 100
$$

The yield: The crop yields were evaluated by taking 4 samples $\left(1 \mathrm{~m}^{2}\right.$ area) randomly selected from each plot. The plants were collected manually and then weighed.

\section{(3) Power requirement and specific energy.}

The power requirement of DC motor was calculated according to Kurt, 1979 by using the following equation:

$$
\mathrm{P}=\mathrm{Ix} \mathrm{V}
$$

Where:

$\mathrm{P}=$ Power requirement for the seed-coating machine in $\mathrm{W}$,

I = Line current strength in amperes,

$\mathrm{V}=$ Potential difference (Voltage) being equal to 6,9 and $12 \mathrm{~V}$,

The Specific energy was calculated by using the following equation:

Specific energy, $\mathrm{kW} . \mathrm{h} / \mathrm{ton}=\frac{\text { Power, } \mathrm{kW}}{\text { Machine capacity, ton } / \mathrm{h}}$

Estimating the costs of using the machine: Cost of operation was calculated according to the equation given by Awady (1978), in the following form:

$$
\mathrm{C}=\mathrm{p} / \mathrm{h}(1 / \mathrm{a}+\mathrm{i}+\mathrm{t} / 2+\mathrm{r})+(\mathrm{Ec} * \mathrm{Ep})+\mathrm{m} / 144
$$


Where: $\mathrm{C}=$ hourly cost, $\mathrm{p}=$ price of machine, $\mathrm{h}=$ yearly working hours, $\mathrm{a}=$ life expectancy of the machine, $\mathrm{i}=$ interest rate/year, $\mathrm{t}=$ taxes, $\mathrm{r}=$ overheads and indirect cost ratio, Ec $=$ Electricity consumption $\mathrm{kW} . \mathrm{h} / \mathrm{h}, \mathrm{Ep}=$ Electricity price L.E/kW.h, "144" are estimated monthly working hours. Notice that all units have to be consistent to result in L.E/h.

Production cost, L.E./ton $=\frac{\text { Operation cost, L.E./h }}{\text { Machine capacity, ton } / \mathrm{h}}$

\section{RESULTS AND DISCUSSION}

Effect of coating temperature, time and speed, by "Fe $+\mathrm{Zn}$ ", "Fe + $\underline{Z n}+$ Cersan" and clay on germination of sesame seeds.

Fig. 5 shows the effect of coating temperature, time, speed and material ("Fe, Zn and Cersan" and clay) on sesame-seed germination.

The maximum sesame-seed germinations of 55.1, 65.3 and $55.8 \%$ were obtained by using coating-unit speed of $28 \mathrm{rpm}$, coating time of 15 minute, coating temperature of $30 \mathrm{C}^{\mathrm{o}}$ and coating with " $\mathrm{Fe}+\mathrm{Zn}$ ", " $\mathrm{Fe}+$ $\mathrm{Zn}+$ Cersan" and clay respectively. Meanwhile, the minimum sesameseed germinations of 2.1, 6.3 and $4.4 \%$ were obtained by using coatingunit speed of $36 \mathrm{rpm}$, coating time of 65 minute, coating temperature of $70 \mathrm{C}^{\mathrm{o}}$ and coating with "Fe $+\mathrm{Zn}$ ", "Fe $+\mathrm{Zn}+\mathrm{Cersan"} \mathrm{and} \mathrm{clay}$ respectively.

The germination of sesame-seeds without coating was $50.1 \%$.

By increasing coating speed from 20 to $28 \mathrm{rpm}$ the sesame-seed germinations increased by $27.5,27.3$ and $15.2 \%$ for coating with " $\mathrm{Fe}+$ $\mathrm{Zn}$ ", "Fe $+\mathrm{Zn}+$ Cersan" and clay respectively. Meanwhile, by increasing coating speed from 28 to $36 \mathrm{rpm}$, the sesame-seed germinations decreased by $31.1,29.8$ and $28.6 \%$ for coating with " $\mathrm{Fe}+\mathrm{Zn}$ ", "Fe $+\mathrm{Zn}$ + Cersan" and clay respectively.

By increasing coating time from 15 to 65 minute the sesame-seed germinations decreased by $68.5,61.4$ and $70.3 \%$ for coating with " $\mathrm{Fe}+$ $\mathrm{Zn}$, "Fe $+\mathrm{Zn}+$ Cersan” and clay respectively. 


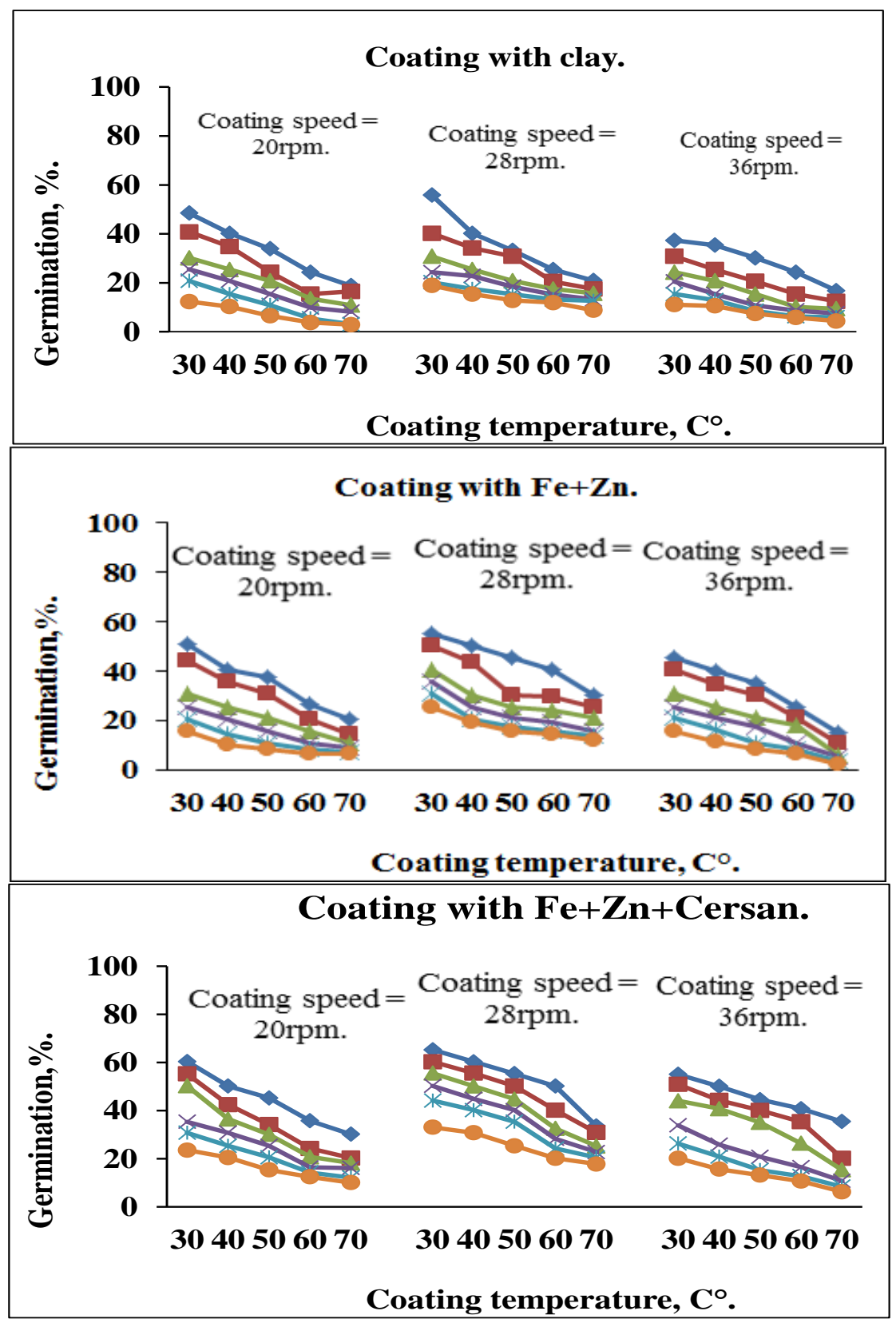

Coating temperature, $\mathrm{C}^{\circ}$.

Coating time, min.

$\multimap 15-25 \multimap 35 \multimap 45 \multimap 55 \multimap 65$

Fig. 5: Effect of coating temperature and time, by "Fe $+\mathrm{Zn}$ ", "Fe $+\mathrm{Zn}+$ Cersan" and clay on sesame-seeds germination. 
By increasing coating temperature from 30 to $70{ }^{0} \mathrm{C}$ the sesame-seed germinations decreased by $12.6-33.5,19.7-44.2$ and $11.4-28.2 \%$ for coating with " $\mathrm{Fe}+\mathrm{Zn}$ ", "Fe $+\mathrm{Zn}+$ Cersan" and clay respectively.

Seed germination increase by coating with "Fe $+\mathrm{Zn}+$ Cersan" may be due to feeding seed-embryo by "Fe $+\mathrm{Zn}$ " and fungicide protection by "Cersan" through seed-germination period.

Increasing germination using seed heat-treatment at $30{ }^{\circ} \mathrm{C}$ may be due to activate seed embryo and accelerating seed germination. .Seed witting by Arabic gum and heating by hot air through seed-coating process is similar to "vernalization" phenomenon which encourages germination and plant flowering.

Decreasing seed-germination at coating-temperature range of $50-70{ }^{\circ} \mathrm{C}$ and coating time $60-65$ minute may be death to die of some embryo seeds.

\section{Effect of coating-unit speed and seed-batch mass on coated-seeds} machine capacity.

Fig. 6 shows effect of coating-unit speed and seed-batch mass on machine capacity of coated sesame-seeds.

The machine capacity of coated sesame-seeds increased by $14.09 \%$ by increasing coating-unit speed from 28 to $36 \mathrm{rpm}$. Meanwhile, the machine capacity of coated sesame-seeds increased by $57.1 \%$ by increasing seedsbatch mass from 0.5 to $2.5 \mathrm{~kg}$.

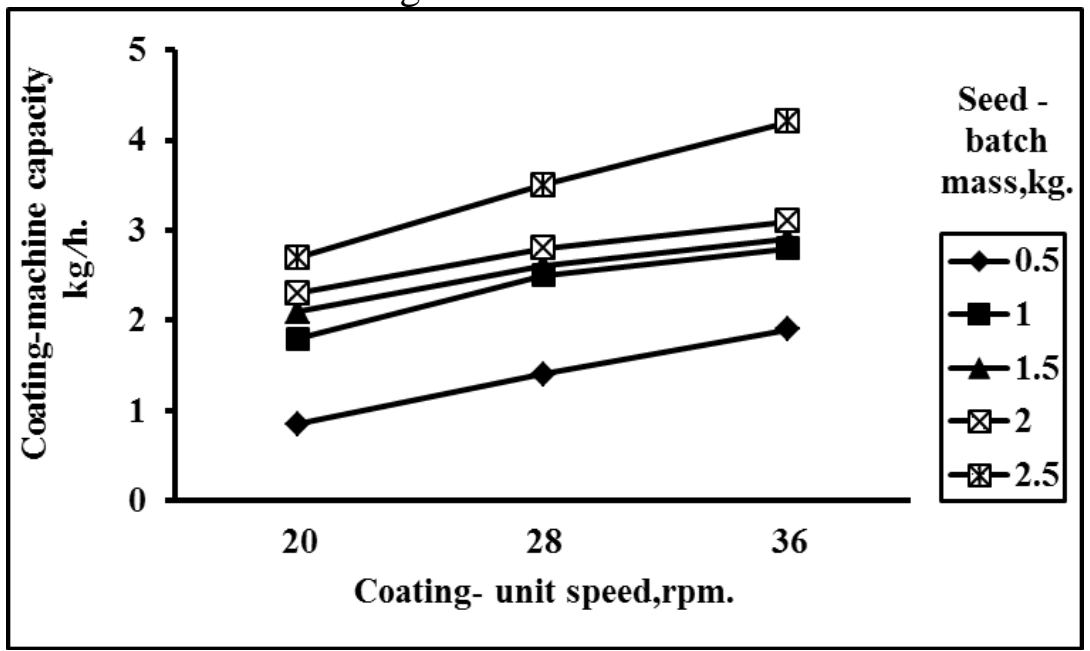

Fig. 6: Effect of coating-unit speed and sesame-seed batch mass on coated-seeds machine capacity. 
The maximum machine capacity of coated sesame-seeds of $4.2 \mathrm{~kg} / \mathrm{h}$ was obtained using seeds-batch mass of $2.5 \mathrm{~kg}$ and coating-unit speed of 36 rpm. Meanwhile, the minimum machine capacity of coated sesame-seeds of $0.85 \mathrm{~kg} / \mathrm{h}$ was obtained using seeds-batch mass of $0.5 \mathrm{~kg}$ and coatingunit speed of $20 \mathrm{rpm}$.

Decreasing machine capacity of coated sesame-seeds at coating-unit speed of $20 \mathrm{rpm}$ is due to increased un-coated seeds after coating process. Meanwhile, increasing machine capacity by increasing coating-unit speed is due to decreasing the coating time.

Physical and mechanical properties of sesame seeds before and after coating at optimum parameters.

Tables 3 and 4 show physical and mechanical properties of sesameseeds before and after coating at optimum parameters of batch mass of $2.5 \mathrm{~kg}$, coating-unit speed of $18 \mathrm{rpm}$, coating temperature of $30{ }^{0} \mathrm{C}$, coating time of 15 minutes and coating with "Fe + Zn + Cersan".

Table 3: Physical properties of sesame-seeds before and after coating at optimum parameters of batch mass of $2.5 \mathrm{~kg}$, coating-unit speed of $28 \mathrm{rpm}$, coating temperature of $30{ }^{\circ} \mathrm{C}$, coating time of 15 minutes and coating with " $\mathrm{Fe}+\mathrm{Zn}+$ Cersan".

\begin{tabular}{|c|c|c|c|c|c|c|c|c|}
\hline \multirow{2}{*}{ Properties } & \multicolumn{4}{|c|}{ Before coating } & \multicolumn{4}{|c|}{ After coating } \\
\hline & Max. & Min. & Av. & C. V. & Max. & Min. & Av. & C. V. \\
\hline $\begin{array}{l}\text { The mass of } 1000 \\
\text { kernel }\end{array}$ & 22.5 & 16.5 & 19.5 & 0.39 & 44.8 & 45 & 44.9 & 0.04 \\
\hline Real density, $\mathrm{kg} / \mathbf{~ m}^{3}$ & 420 & 400 & 410 & 0.15 & 450 & 420 & 435 & 0.18 \\
\hline Bulk density, kg/ m³ & 392 & 387 & 389 & 0.08 & 433 & 410 & 421 & 0.16 \\
\hline $\begin{array}{l}\text { Dimensions: } \\
\text { Length, mm. } \\
\text { Width, mm } \\
\text { Thickness, mm }\end{array}$ & $\begin{array}{l}4.15 \\
3.46 \\
2.43\end{array}$ & $\begin{array}{l}3.76 \\
3.22 \\
2.10\end{array}$ & $\begin{array}{c}3.95 \\
3.34 \\
2.3\end{array}$ & $\begin{array}{l}0.22 \\
0.18 \\
0.53\end{array}$ & $\begin{array}{l}4.66 \\
3.89 \\
2.55\end{array}$ & $\begin{array}{l}4.43 \\
3.41 \\
2.31\end{array}$ & $\begin{array}{l}4.51 \\
3.65 \\
2.42\end{array}$ & $\begin{array}{l}0.15 \\
0.25 \\
0.22\end{array}$ \\
\hline Volume, $\mathbf{m m}^{3}$ & 18.3 & 13.3 & 15.8 & 0.3 & 24.2 & 18.2 & 20.8 & 0.37 \\
\hline Projected area, mm$^{2}$ & 11.2 & 9.5 & 10.4 & 0.28 & 18.1 & 15.1 & 12.9 & 0.34 \\
\hline
\end{tabular}

Max: maximum, Min.: minimum, Av.: average and C. V.: coefficient of variation.

Tables 3 shows that averages of mass of 1000 kernel before and after coating are 19.5 and $44.9 \mathrm{~g}$. Averages of seed length, width and thickness 
before coating were " $3.95,3.34$ and $2.3 \mathrm{~mm}$ " and after coating were 4.51 , 3.65 and 2.42 respectively. Average of bulk and real densities before coating were 389 and $410 \mathrm{~kg} / \mathrm{m}^{3}$ and after coating are 421 and $435 \mathrm{~kg} / \mathrm{m}^{3}$ respectively. Averages of sesame seed volume before and after coating were 15.8 and $20.8 \mathrm{~mm}^{3}$. Averages of projected area of sesame seeds before and after coating were 10.4 and $12.9 \mathrm{~mm}^{2}$ respectively.

Table 3 shows that maximum friction-angle with glass, wood, stainless steel, copper, galv. iron-sheet and iron sheet before coating are 14.12, $20.11,15.14,25.32,13.10$ and 16.29 degree respectively and after coating are 19.20, 23.55, 17.88, 28.22, 16.54 and 19.33 degree. Averages of angle of repose before and after coating are 13.6 and 19.1 respectively. Meanwhile, the maximum repose-angles before and after coating are 14.1 and 20.1 degree respectively.

Table 4: Mechanical properties of sesame-seeds before and after coating at optimum parameters of batch mass of $2.5 \mathrm{~kg}$, coating-unit speed of $18 \mathrm{rpm}$, coating temperature of $30{ }^{\circ} \mathrm{C}$, coating time of 15 minutes and coating with "Fe $+\mathrm{Zn}+\mathrm{Cersan"}$ "

\begin{tabular}{|l|c|c|c|c|c|c|}
\hline \multirow{2}{*}{\multicolumn{1}{c|}{ Properties }} & \multicolumn{3}{|c|}{ Before coating } & \multicolumn{3}{c|}{ After coating } \\
\cline { 2 - 7 } & Max. & Min. & Av. & Max. & Min. & Av. \\
\hline Angle of repose & 14.1 & 12.2 & 13.6 & 20.1 & 18.1 & 19.1 \\
\hline Friction angle: & & & & & & \\
- Glass & 14.12 & 12.15 & 13.1 & 19.20 & 16.32 & 17.7 \\
- Wood & 20.11 & 17.13 & 18.6 & 23.55 & 20.76 & 22.1 \\
- Stainless steel & 15.14 & 13.21 & 14.4 & 17.88 & 16.34 & 16.65 \\
- Copper & 25.32 & 22.54 & 23.9 & 28.22 & 21.5 & 24.8 \\
- Galv. iron-sheet & 13.10 & 12.11 & 12.8 & 16.54 & 14.32 & 15.4 \\
- Iron sheet & 16.29 & 14.31 & 15.7 & 19.33 & 17.84 & 18.27 \\
\hline
\end{tabular}

Max: maximum, Min.: minimum, Av.: average .and Galv.: Galvanized.

\section{Effect of soil moisture-content, soluble time on coating-film solubility} in soil.

Fig. 7 shows the effect of soil moisture-content, soluble time on solubility of coating films for sesame-seeds. 
The maximum solubility of coated films for sesame-seeds of $100 \%$ was obtained using soluble time of $30 \mathrm{~h}$ and soil moisture-content of $100 \%$. Meanwhile, the minimum solubility of coated films for sesame-seeds of $24 \%$ was obtained using soluble time $6 \mathrm{~h}$ and soil moisture-content of $10 \%$.

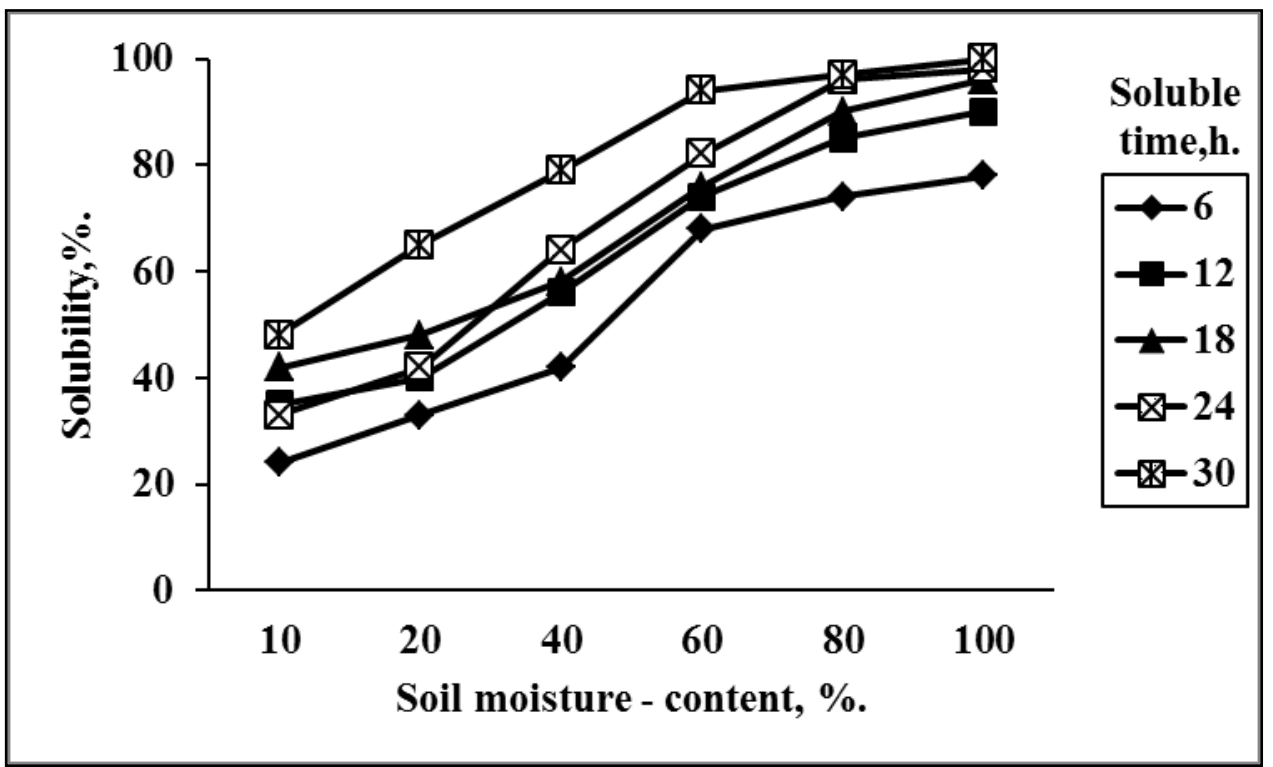

Fig.7: Effect of soil moisture-content, soluble time on coating-film solubility of sesame-seeds.

Effect of coating unit speed on power requirement and specific energy.

Figs. 8 and 9 show the effect of coating-unit speed and sesame-seed batch mass on power requirement and specific energy.

The maximum power and specific energy of $31.2 \mathrm{~W}$ and $18.4 \mathrm{~kW} . \mathrm{h} / \mathrm{ton}$ was obtained at coating-unit speed of $36 \mathrm{rpm}$ and seed batch-mass of 0.5 $\mathrm{kg}$. Meanwhile, the minimum power and specific energy of $15.6 \mathrm{~W}$ and $5.8 \mathrm{~kW} . \mathrm{h} /$ ton was obtained at coating-unit speed of $28 \mathrm{rpm}$ seed batchmass of $2.5 \mathrm{~kg}$. 


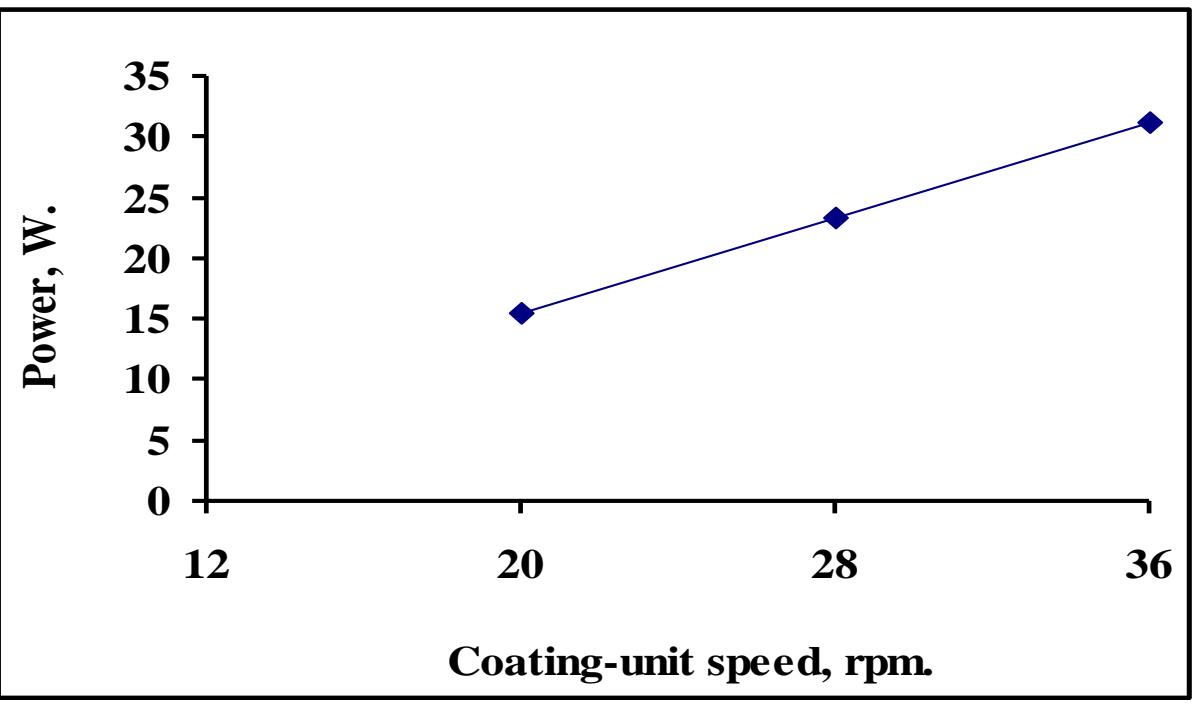

Fig. 8: Effect of coating-unit speed and sesame-seed batch mass on power requirement.

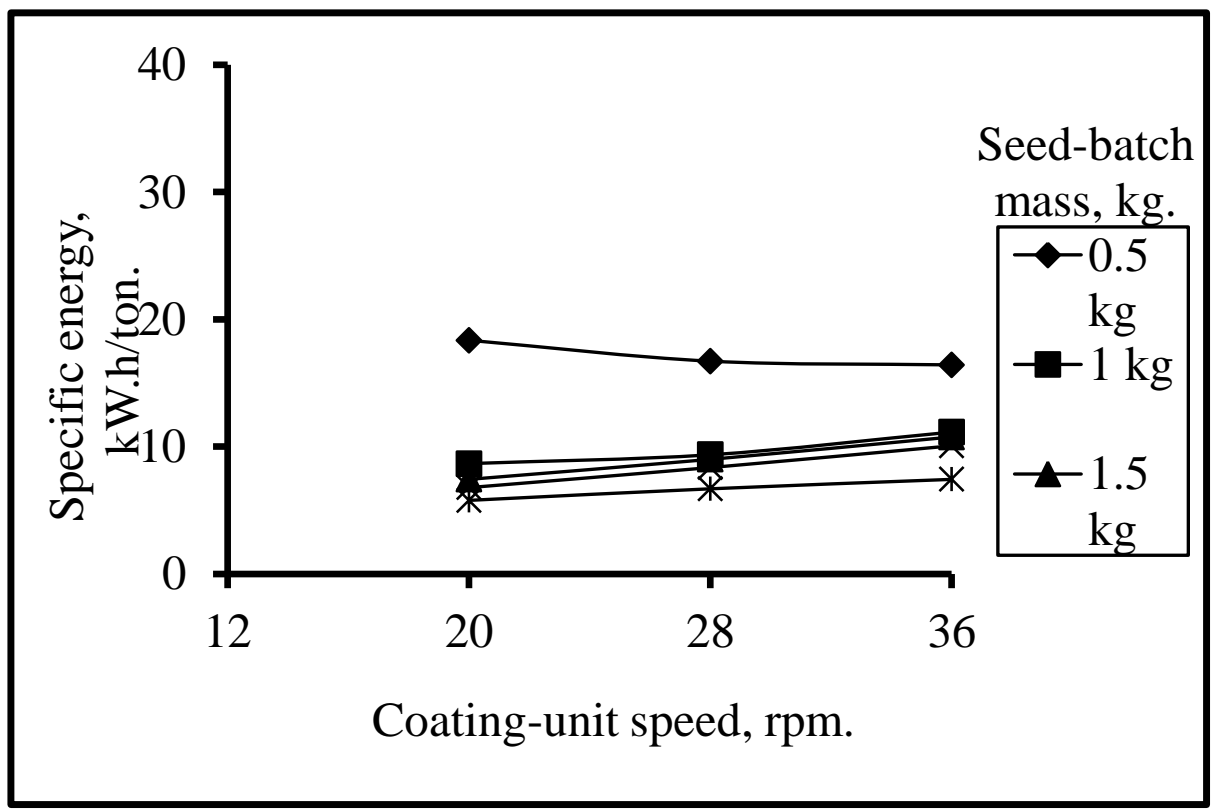

Fig. 9: Effect of coating-unit speed and sesame-seed batch mass on specific energy.

\section{Cost of using the designed a seed coating machine.}

Table 5 shows the components of the Awady equation and operation and production costs of using the designed a seed coating-machine. 
Table 5: The components of Awady equation.

\begin{tabular}{|c|c|c|c|c|c|c|c|c|}
\hline p, L.E. & h, h & a, year & $\mathrm{i}$ & $\mathrm{t}$ & $\mathrm{r}$ & $\mathrm{Ec}, \mathrm{kW} . \mathrm{h} / \mathrm{h}$ & Ep, L.E. & m, L.E \\
\hline 2000 & 2000 & 10 & 0.075 & 0.05 & 0.03 & $0.016-0.031$ & 0.30 & 1500 \\
\hline
\end{tabular}

$$
\begin{gathered}
\mathrm{C}=2000 / 2000\{(1 / 10)+0.075+(0.05 / 2)+0.03\}+(0.031 * \\
0.30)+(1500 / 144)=10.63 \text { L.E. } / \mathrm{h} .
\end{gathered}
$$

The operation and production costs at optimum parameters (batch mass of $2.5 \mathrm{~kg}$, coating-unit speed of $28 \mathrm{rpm}$, coating temperature of $30{ }^{\circ} \mathrm{C}$, coating time of 15 minutes and coating with " $\mathrm{Fe}+\mathrm{Zn}+$ Cersan") were 10.63 L. E./h and 3037 L.E./ton.

The production cost of sesame fruits by using coated seeds with "Fe $+\mathrm{Zn}+$ Cersan was about" $0.98-1.18$ L. E./kg. Meanwhile, the production cost of sesame fruits by using the traditional seedlings was about 1.27 L. E./kg.

\section{CONCLUSION}

The optimum conditions of coating machine were: coating-unit speed of $28 \mathrm{rpm}$, coating temperature of $30 \mathrm{C}^{\mathrm{o}}$, coating time $15 \mathrm{~min}$, Arabic-gum temperature and concentration $50-70 \mathrm{C}^{\mathrm{o}}$ and $25-75 \%$, coating with "Fe $+\mathrm{Zn}+$ Cersan" and seed-batch mass $2.5 \mathrm{~kg}$. The results obtained at optimum conditions of sesame were: see of $65.3 \%$, coating-machine capacity $=4.2 \mathrm{~kg} / \mathrm{h}$, specific energy $=5.8 \mathrm{~kW} . \mathrm{h} / \mathrm{ton}$ seeds coated and costs of 10.63 L. E./h and 2725.6 L.E./ton.

\section{REFFERENCES}

Abd-Al Fattah' Y.A. Bahnasawy, A. A., Yehia, I. and Hassan, T. A. , 2015, Development of a seed-coating machine for pepper crop.,The 20th Annual Conference of Misr Soc. of Ag. Eng.:171-192.

Abd-Al Fattah' Y.A., 2016, Development of a seed-coating machine for some crops, Ph. D., Ag. And Bio-systems Eng. Dept., Fac. of Agriculture, Moshtohor, Banha Univ.: 17-124.

Agricultural Economics Issue, 2006, Central Management of Ag. Economics, Ministry of Ag., Egypt: $1-5$.

Awady, M. N., 1978, Tractors and farm machines, in Arabic, text. Col. Ag., A. Shams U.: 164-167.

Burris, J. S., Prijic, L. M. And Chen, Y., 1994, A small-scale laboratory fluidized bed seed-coating apparatus, in Martin, T. (Ed.), Seed Treatmrent Progress and Prospects, Surrey, British Crop Prot. Council.: 419-423. 
Duan, X. And Burris, J. S., 1997, Film coating impairs leaching of germination inhibitors in sugar beet seeds, Crop Science 37 :515520.

El-Habbal, M. S.; Osman, A. O. and Badran, M. M., 1995, Effect of some micronutrients fertilizer and transplanting on wheat production in newly reclaimed saline soil, Annals of Agric. Sc., Ain Shams U., Egypt, 40(1): 145-152.

Gontard, N., C. Duchez, B. Cuq, and S. Guilbert. 1994. Edible composite films of wheat gluten and lipids: water vapour permeability and other physical properties. Food Sci.Technol. 29:39-50.

Halmer, P., 1988, Technical and commercial aspects of seed pelleting and film-coating in Martin, T. (Ed.), Seed Treatmrent Progress and Prospects, Surrey, British Crop Protection Council: 191-204.

Hill, H. J., 1997, New developments in seed technology, Proceedings of the Oregon Hort. Soc., Portland, Oregon 88: 123-130.

Kurt, G., 1979, Engineering formulas, $3^{\text {rd }}$ Ed., MacGraw Hill Book N. Y.

McGee, D. C., 1995, Advances in seed treatment technology, Technical report no. 11, in McNicoll, A. (Ed.) Proc. Asia and Pacific Seed Assoc., New Delhi, APSA. :1-14

Ni, B. R., 1997, Seed coating, film coating and pelleting, pp 737-747 in Chinese Assoc. of Ag. Sci., DDA, Minis. of Ag., PR China and China Nat. Seed Group Cooperation, (ED.), Seed industry and ag. Dev., Bejing, China Ag. Press.

Rehm, G., 2003, Tactics to reduce yield loss from iron deficiency chlorosis, Dept. of Soil, Water and Climate, U. of Minnesota, www.plpa.agri.

umn.edu /extension/news releases Net Cite, 19 Nov. 2003: 1-9.

Robani, H., 1994, Film-coating horticultural seed, HorTech. 4: 104-104.

Taylor, A. G. And Eckenrode, C. J., 1993, Seed coating technologies to apply Trigard for the control of onion maggot and to reduce pesticide application, in Efforts pertinent to the integrated pest manag. effort at Corrnel U., NYS IPM Pub. 117 : 73-78.

Taylor. A. G., Harman, G. E. and Nielsen, P. A., 1994, Biological seed treatments using Trichodrina harzianum for horticultural crops, HorTech. 4: 105-109. 
Taylor, A. G., Allen, P. S., Bennett, M. A., Bardford, K. J., Burris, J. S. And Misra, M. K., 1998, Seed enhancements, Seed Sc. Res. 8, USA: $245-256$.

Yehia, I., 2008, Factors affecting the design of coating machine for crop seeds, Misr J. Ag. Eng., 25(1): 147-159.

Yehia, I., Eliwa. A. A., El Lithy, A. M., Attallah. M., 2010, Effect of coating temperature and time on germination of some aromatic and medical seeds, Misr J. Ag. Eng., 35(4): 1710-1720.

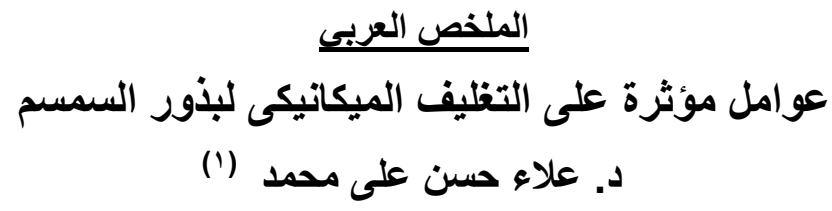

يهدف هذا البحث إلى دراسة العوامل المؤثرة على التغليف الميكانيكى لبذور السمسم. وكانت

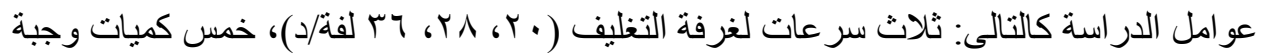

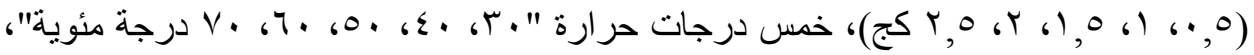

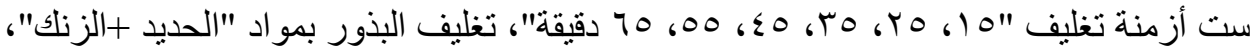

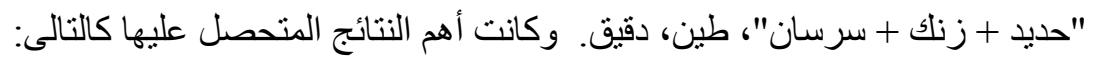

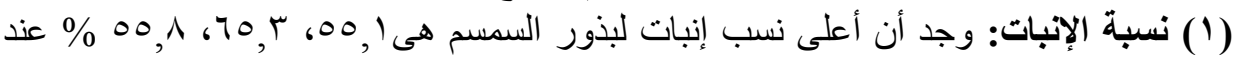

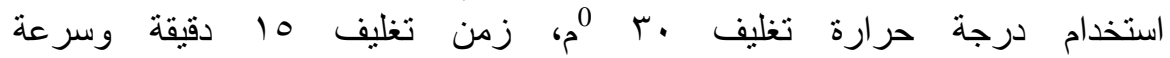

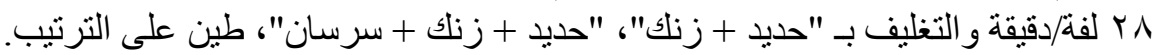

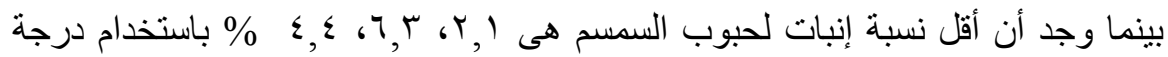

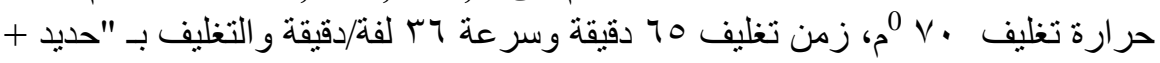
زنك"، "حديد + زنك + سرسان"، طين على الترتيب. وكانت نسبة الإنبات لبذور السمسم

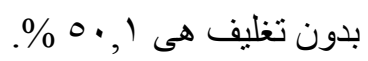

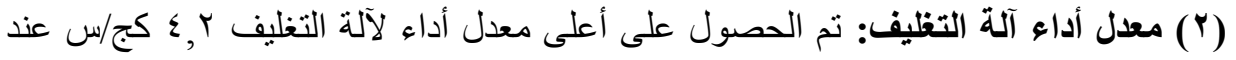

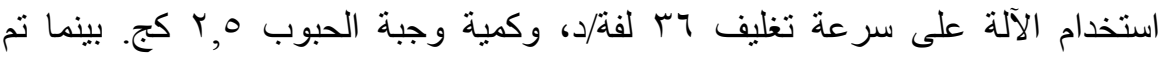

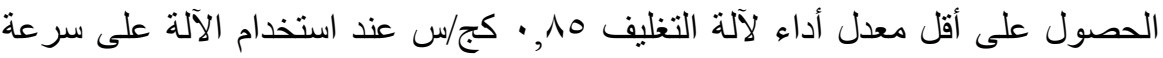

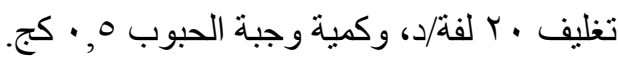

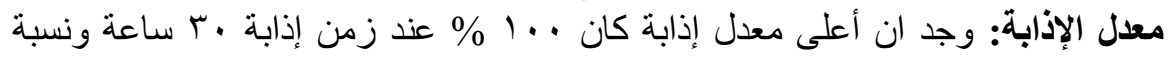

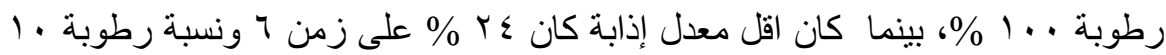
$\%$

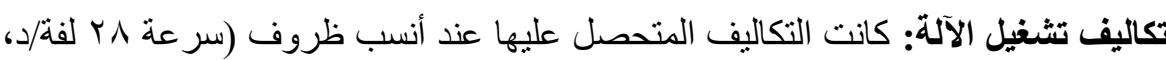

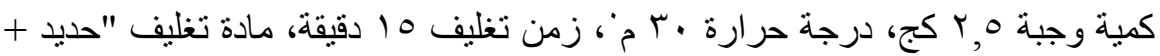

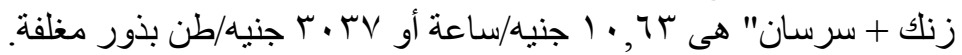

